Supporting information for

\title{
Effects of Sucrose on Phase Transitions of Organic/Inorganic Aerosols
}

\author{
Emily-Jean E. Ott, Emma C. Tackman, Miriam Arak Freedman* \\ Department of Chemistry, The Pennsylvania State University, University Park, Pennsylvania 16802
}

Number of Pages: 13

Number of Figures: 3

Number of Tables: 4 
Summary: The supporting information contains a table with all the intermediate data points shown in the SRH, ERH, and DRH figures and a figure showing the two steps of efflorescence of 3,3-dimethylglutaric acid/sodium chloride/sucrose particles. Also included is the process for obtaining viscosity information as well as a discussion of the effects of viscosity, surface tension, and density on the phase separation of the studied systems.

Table S1: The SRH, MRH, and DRH and average O:C values for all intermediate data points

\begin{tabular}{|c|c|c|c|c|c|c|}
\hline & & $\begin{array}{c}\% \\
\text { Sucrose }\end{array}$ & $\begin{array}{c}\text { Average } \\
\text { O:C }\end{array}$ & SRH & ERH & DRH \\
\hline \multirow{9}{*}{ 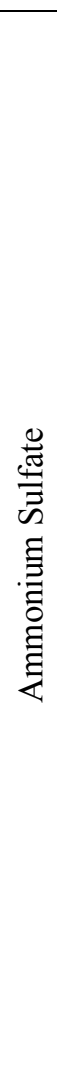 } & 2-Methylglutaric Acid & $1 \%$ & 0.703 & $\begin{array}{c}63.7 \pm 0(15) \\
a\end{array}$ & $\begin{array}{c}37.7 \pm 2.6 \\
(17)\end{array}$ & $85.9 \pm 1.1(19)$ \\
\hline & \multirow{4}{*}{$\begin{array}{c}\text { 3,3-Dimethylglutaric } \\
\text { Acid }\end{array}$} & $3 \%$ & 0.698 & $84.9 \pm 0(14)$ & $\begin{array}{c}42.8 \pm 2.3 \\
(16)\end{array}$ & $--^{b}$ \\
\hline & & $7 \%$ & 0.773 & $\begin{array}{l}72.0 \pm 0.5 \\
(20)\end{array}$ & -- & -- \\
\hline & & $10 \%$ & 0.805 & $\begin{array}{l}63.4 \pm 0.1 \\
(13)\end{array}$ & $\begin{array}{c}44.3 \pm 4.4 \\
(12)\end{array}$ & -- \\
\hline & & $13.75 \%$ & 0.830 & $\begin{array}{l}60.7 \pm 1.3 \\
(16)\end{array}$ & $\begin{array}{c}46.4 \pm 2.8 \\
(15)\end{array}$ & -- \\
\hline & \multirow{2}{*}{$\begin{array}{l}\text { Polyethylene glycol } \\
1000\end{array}$} & $20 \%$ & 0.904 & $\begin{array}{l}52.2 \pm 0.3 \\
(21)\end{array}$ & -- & -- \\
\hline & & $30 \%$ & 0.909 & $\begin{array}{l}39.2 \pm 0.7 \\
\quad(11)\end{array}$ & -- & -- \\
\hline & \multirow{2}{*}{$\begin{array}{l}\text { Polyethylene Glycol } \\
12000\end{array}$} & $20 \%$ & 0.915 & $83.6 \pm 0(24)$ & -- & -- \\
\hline & & $30 \%$ & 0.916 & $\begin{array}{c}68.6 \pm 0.1 \\
(12)\end{array}$ & -- & -- \\
\hline \multirow{4}{*}{ 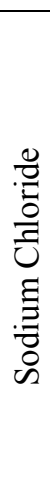 } & \multirow{4}{*}{ 2-Methylglutaric Acid } & $1 \%$ & 0.703 & $\begin{array}{c}54.9 \pm 1.0 \\
(23)\end{array}$ & $\begin{array}{c}57.0 \pm 5.2 \\
(16)\end{array}$ & $81.9 \pm 0.3(16)$ \\
\hline & & $1.5 \%$ & 0.719 & $\begin{array}{l}54.0 \pm 0.1 \\
(12)\end{array}$ & $\begin{array}{c}54.7 \pm 5.5 \\
(17)\end{array}$ & $81.8 \pm 0(17)$ \\
\hline & & $1.75 \%$ & 0.725 & $\begin{array}{c}52.8 \pm 1.0 \\
(15)\end{array}$ & $\begin{array}{c}53.6 \pm 5.8 \\
(30)\end{array}$ & $77.5 \pm 1.8(30)$ \\
\hline & & $2 \%$ & 0.731 & $\begin{array}{c}57.3 \pm 1.6 \\
(21)\end{array}$ & $\begin{array}{c}53.3 \pm 5.2 \\
(23)\end{array}$ & $78.5 \pm 0.1(17)$ \\
\hline
\end{tabular}




\begin{tabular}{|c|c|c|c|c|c|c|}
\hline & & $5 \%$ & 0.785 & $\begin{array}{c}44.8 \pm 3.4 \\
\quad(11)\end{array}$ & $\begin{array}{l}45.8 \pm 8.2 \\
(22)\end{array}$ & $77.1 \pm 0.1(22)$ \\
\hline & \multirow{2}{*}{ 3-Methylglutaric Acid } & $1 \%$ & 0.703 & $\begin{array}{l}52.3 \pm 1.1 \\
(14)\end{array}$ & $\begin{array}{l}51.4 \pm 5.8 \\
(17)\end{array}$ & $78.3 \pm 0.1(17)$ \\
\hline & & $1.5 \%$ & 0.718 & $\begin{array}{l}50.2 \pm 1.4 \\
(12)\end{array}$ & $\begin{array}{l}50.4 \pm 5.3 \\
(14)\end{array}$ & $78.4 \pm 0.2(14)$ \\
\hline & \multirow{7}{*}{$\begin{array}{c}\text { 3,3-Dimethylglutaric } \\
\text { Acid }\end{array}$} & $3 \%$ & 0.698 & $76.0 \pm 0(12)$ & $\begin{array}{l}51.5 \pm 2.9 \\
(2)\end{array}$ & -- \\
\hline & & $7 \%$ & 0.773 & $74.3 \pm 0(12)$ & $\begin{array}{c}45.2 \pm 6.4 \\
(8)\end{array}$ & -- \\
\hline & & $10 \%$ & 0.805 & $\begin{array}{l}68.3 \pm 1.3 \\
(12)\end{array}$ & $\begin{array}{l}35.6 \pm 6.5 \\
(10)\end{array}$ & -- \\
\hline & & $13 \%$ & 0.826 & $65.1 \pm 0(10)$ & $\begin{array}{l}45.1 \pm 4.7 \\
\quad(6)\end{array}$ & -- \\
\hline & & $17 \%$ & 0.845 & $\begin{array}{l}62.1 \pm 1.1 \\
(22)\end{array}$ & $\begin{array}{l}44.1 \pm 2.4 \\
\text { (7) }\end{array}$ & -- \\
\hline & & $20 \%$ & 0.856 & $\begin{array}{l}54.5 \pm 0.5 \\
(23)\end{array}$ & $\begin{array}{l}44.2 \pm 5.6 \\
\text { (7) }\end{array}$ & -- \\
\hline & & $23 \%$ & 0.864 & $\begin{array}{l}50.1 \pm 0.2 \\
\quad(10)\end{array}$ & $\begin{array}{l}36.2 \pm 11.1 \\
\quad(15)\end{array}$ & -- \\
\hline & \multirow{2}{*}{$\begin{array}{l}\text { Polyethylene glycol } \\
\qquad 1000\end{array}$} & $1 \%$ & 0.736 & $\begin{array}{c}47.9 \pm 0.5 \\
(43)\end{array}$ & $\begin{array}{c}49.4 \pm 5.0 \\
(59)\end{array}$ & $82.8 \pm 0.2(30)$ \\
\hline & & $1.25 \%$ & 0.758 & $\begin{array}{l}47.0 \pm 0.2 \\
\text { (13) }\end{array}$ & $\begin{array}{l}51.3 \pm 5.3 \\
\quad(25)\end{array}$ & $81.2 \pm 0.2(15)$ \\
\hline & \multirow{3}{*}{$\begin{array}{l}\text { Polyethylene Glycol } \\
12000\end{array}$} & $1.5 \%$ & 0.898 & $\begin{array}{l}63.5 \pm 0.8 \\
(30)\end{array}$ & $\begin{array}{l}49.9 \pm 5.7 \\
(30)\end{array}$ & $80.3 \pm 0.2(15)$ \\
\hline & & $2 \%$ & 0.903 & $60.8 \pm 0(11)$ & $\begin{array}{l}56.3 \pm 5.3 \\
\quad(13)\end{array}$ & $77.2 \pm 0(13)$ \\
\hline & & $3 \%$ & 0.907 & $\begin{array}{l}56.9 \pm 0.6 \\
(55)\end{array}$ & $\begin{array}{l}49.3 \pm 6.0 \\
\quad(40)\end{array}$ & $77.6 \pm 0.3(44)$ \\
\hline \multirow{2}{*}{ 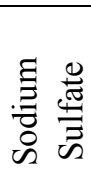 } & \multirow{2}{*}{$\begin{array}{c}\text { 3,3-Dimethylgluartic } \\
\text { Acid }\end{array}$} & $10 \%$ & 0.805 & $73.0 \pm 0(16)$ & $(0)^{\mathrm{c}}$ & -- \\
\hline & & $14 \%$ & 0.831 & $\begin{array}{l}48.7 \pm 1.6 \\
\quad(10)\end{array}$ & $\begin{array}{l}42.2 \pm 2.7 \\
\text { (11) }\end{array}$ & $91.7 \pm 0(5)$ \\
\hline
\end{tabular}




\begin{tabular}{|c|c|c|c|c|c|c|}
\hline & & $17 \%$ & 0.845 & $\begin{array}{c}54.7 \pm 1.3 \\
(17)\end{array}$ & (0) & (0) \\
\hline & Polyethylene Glycol & $20 \%$ & 0.915 & $\begin{array}{c}87.7 \pm 0.0 \\
(15)\end{array}$ & -- & -- \\
\hline & 12000 & $40 \%$ & 0.916 & $\begin{array}{c}73.3 \pm 1.6 \\
(23)\end{array}$ & -- & -- \\
\hline & & $2 \%$ & 0.667 & $\begin{array}{l}69.5 \pm 0.1 \\
(16)\end{array}$ & $(0)$ & -- \\
\hline & & $5 \%$ & 0.743 & $\begin{array}{c}64.33 \pm 0 \\
(13)\end{array}$ & $\begin{array}{c}48.55 \pm 4.9 \\
\text { (2) }\end{array}$ & -- \\
\hline & $\begin{array}{l}\text { 3,3-Dimethylgluartic } \\
\text { Acid }\end{array}$ & $10 \%$ & 0.805 & $\begin{array}{l}63.8 \pm 1.1 \\
(12)\end{array}$ & $\begin{array}{c}46.8 \pm 5.3 \\
(12)\end{array}$ & -- \\
\hline & & $28.25 \%$ & 0.875 & $\begin{array}{l}47.7 \pm 1.6 \\
(15)\end{array}$ & $41.4 \pm 0(1)$ & -- \\
\hline $\begin{array}{l}\text { E } \\
\Xi\end{array}$ & & $30 \%$ & 0.878 & $\begin{array}{l}46.3 \pm 1.0 \\
(11)\end{array}$ & $\begin{array}{l}55.1 \pm 0.3 \\
\text { (2) }\end{array}$ & -- \\
\hline E & & $1 \%$ & 0.889 & $50.9 \pm 0(3)$ & $\begin{array}{c}44.9 \pm 3.7 \\
(5)\end{array}$ & $74.5 \pm 0.1(6)$ \\
\hline & & $2 \%$ & 0.902 & $47.3 \pm 0(5)$ & $39.3 \pm 2.9$ & $74.2 \pm 0.9(11)$ \\
\hline & 12000 & $3 \%$ & 0.907 & $42.6 \pm 0(9)$ & $\begin{array}{c}35.5 \pm 2.2 \\
\text { (9) }\end{array}$ & $72.9 \pm 0.2(12)$ \\
\hline & & $4.25 \%$ & 0.910 & $\begin{array}{l}33.5 \pm 0.2 \\
\text { (9) }\end{array}$ & $\begin{array}{l}31.5 \pm 2.9 \\
(6)\end{array}$ & $70.1 \pm 0.2(9)$ \\
\hline
\end{tabular}

a the values in parenthesis are the number of data points taken.

$\mathrm{b}$-- represent when no phase transition was found

${ }^{c}(0)$ are when no data was collected for that phase transition 
Table S2: The wt $\%$ sucrose, sucrose dry mass fraction, phase separating organic to sucrose ratio, average $\mathrm{O}: \mathrm{C}$, and the organic : inorganic ratio for all systems.

\begin{tabular}{|c|c|c|c|c|c|c|}
\hline & Organic Component & $\begin{array}{c}\mathrm{Wt} \% \\
\text { Sucrose }\end{array}$ & $\begin{array}{l}\text { Sucrose } \\
\text { Dry Mass } \\
\text { Fraction }\end{array}$ & $\begin{array}{l}\text { Organic / } \\
\text { Sucrose }\end{array}$ & $\begin{array}{l}\text { Av. } \\
\text { O:C }\end{array}$ & OIR \\
\hline \multirow{27}{*}{ 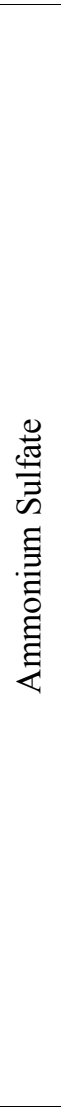 } & \multirow{4}{*}{ 2-Methylglutaric Acid } & $0.00 \%$ & 0.000 & 0.000 & 0.667 & 1.00 \\
\hline & & $1.00 \%$ & 0.168 & 0.712 & 0.703 & 1.404 \\
\hline & & $1.25 \%$ & 0.202 & 0.664 & 0.711 & 1.51 \\
\hline & & $1.50 \%$ & 0.233 & 0.621 & 0.718 & 1.61 \\
\hline & \multirow{3}{*}{ 3-Methylglutaric Acid } & $0.00 \%$ & 0.000 & 0.000 & 0.667 & 1.00 \\
\hline & & $1.00 \%$ & 0.168 & 0.72 & 0.703 & 1.41 \\
\hline & & $1.25 \%$ & 0.202 & 0.66 & 0.711 & 1.51 \\
\hline & \multirow{7}{*}{ 3,3-Dimethylglutaric Acid } & $0.00 \%$ & 0.000 & 0.000 & 0.571 & 1.00 \\
\hline & & $3.00 \%$ & 0.382 & 0.447 & 0.698 & 2.24 \\
\hline & & $7.00 \%$ & 0.601 & 0.249 & 0.773 & 4.01 \\
\hline & & $10.00 \%$ & 0.690 & 0.184 & 0.805 & 5.44 \\
\hline & & $13.75 \%$ & 0.761 & 0.136 & 0.830 & 7.38 \\
\hline & & $14.25 \%$ & 0.769 & 0.131 & 0.833 & 7.65 \\
\hline & & $14.5 \%$ & 0.772 & 0.128 & 0.834 & 7.78 \\
\hline & \multirow{3}{*}{$\begin{array}{l}\text { 2,2-Bis(hydroxymethyl)butyric } \\
\text { Acid }\end{array}$} & $0.00 \%$ & 0.000 & 0.000 & 0.667 & 1.00 \\
\hline & & N/A & N/A & N/A & N/A & $\mathrm{N} / \mathrm{A}$ \\
\hline & & $0.25 \%$ & 0.048 & 0.909 & 0.677 & 1.10 \\
\hline & \multirow{5}{*}{ PEG 1000} & $0.00 \%$ & 0.000 & 0.000 & 0.523 & 1.00 \\
\hline & & $20.00 \%$ & 0.833 & 0.091 & 0.904 & 11.00 \\
\hline & & $30.00 \%$ & 0.896 & 0.055 & 0.909 & 18.2 \\
\hline & & $32.75 \%$ & 0.907 & 0.049 & 0.910 & 20.5 \\
\hline & & $33.0 \%$ & 0.908 & 0.048 & 0.910 & 20.7 \\
\hline & \multirow{5}{*}{ PEG 12000} & $0.00 \%$ & 0.000 & 0.000 & 0.500 & 1.00 \\
\hline & & $20.00 \%$ & 0.833 & 0.091 & 0.915 & 11.0 \\
\hline & & $30.00 \%$ & 0.896 & 0.055 & 0.916 & 18.1 \\
\hline & & $34.75 \%$ & 0.914 & 0.045 & 0.916 & 22.3 \\
\hline & & $35.0 \%$ & 0.915 & 0.044 & 0.916 & 22.5 \\
\hline \multirow{19}{*}{ 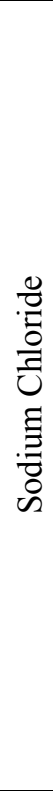 } & \multirow{8}{*}{ 2-Methylglutaric Acid } & $0.00 \%$ & 0.000 & 0.000 & 0.667 & 1.00 \\
\hline & & $1.00 \%$ & 0.168 & 0.712 & 0.703 & 1.40 \\
\hline & & $1.50 \%$ & 0.233 & 0.621 & 0.719 & 1.61 \\
\hline & & $1.75 \%$ & 0.263 & 0.584 & 0.725 & 1.71 \\
\hline & & $2.00 \%$ & 0.290 & 0.551 & 0.731 & 1.82 \\
\hline & & $5.00 \%$ & 0.513 & 0.322 & 0.785 & 3.11 \\
\hline & & $5.75 \%$ & 0.550 & 0.291 & 0.794 & 3.44 \\
\hline & & $6.00 \%$ & 0.561 & 0.281 & 0.797 & 3.55 \\
\hline & \multirow{5}{*}{ 3-Methylglutaric Acid } & $0.00 \%$ & 0.000 & 0.000 & 0.667 & 1.00 \\
\hline & & $1.00 \%$ & 0.168 & 0.712 & 0.703 & 1.40 \\
\hline & & $1.50 \%$ & 0.233 & 0.621 & 0.718 & 1.61 \\
\hline & & $1.75 \%$ & 0.263 & 0.584 & 0.725 & 1.71 \\
\hline & & $2.00 \%$ & 0.290 & 0.551 & 0.731 & 1.82 \\
\hline & \multirow{6}{*}{ 3,3-Dimethylglutaric Acid } & $0.00 \%$ & 0.000 & 0.000 & 0.571 & 1.00 \\
\hline & & 3.00 & 0.382 & 0.447 & 0.698 & 2.24 \\
\hline & & 7.00 & 0.601 & 0.249 & 0.773 & 4.01 \\
\hline & & 10.00 & 0.690 & 0.184 & 0.805 & 5.44 \\
\hline & & 13.00 & 0.749 & 0.143 & 0.826 & 6.98 \\
\hline & & 17.00 & 0.804 & 0.109 & 0.845 & 9.19 \\
\hline
\end{tabular}




\begin{tabular}{|c|c|c|c|c|c|c|}
\hline & & 20.00 & 0.833 & 0.091 & 0.856 & 11.0 \\
\hline & & 23.00 & 0.857 & 0.077 & 0.864 & 12.9 \\
\hline & & $27.75 \%$ & 0.885 & 0.061 & 0.875 & 16.4 \\
\hline & & $28.0 \%$ & 0.886 & 0.060 & 0.875 & 16.6 \\
\hline & & $0.00 \%$ & 0.000 & 0.000 & 0.523 & 1.00 \\
\hline & & $1.00 \%$ & 0.168 & 0.712 & 0.736 & 1.40 \\
\hline & PEG 1000 & $1.25 \%$ & 0.202 & 0.664 & 0.758 & 1.51 \\
\hline & & $1.50 \%$ & 0.233 & 0.621 & 0.775 & 1.61 \\
\hline & & $1.75 \%$ & 0.263 & 0.584 & 0.789 & 1.71 \\
\hline & & $0.00 \%$ & 0.000 & 0.000 & 0.502 & 1.00 \\
\hline & & $1.50 \%$ & 0.233 & 0.621 & 0.898 & 1.61 \\
\hline & DГC 10000 & $2.00 \%$ & 0.290 & 0.551 & 0.903 & 1.81 \\
\hline & PEG 12000 & $3.00 \%$ & 0.382 & 0.447 & 0.907 & 2.24 \\
\hline & & $5.50 \%$ & 0.538 & 0.300 & 0.912 & 3.33 \\
\hline & & $5.75 \%$ & 0.550 & 0.290 & 0.912 & 3.44 \\
\hline & & $0.00 \%$ & 0.000 & 0.000 & 0.571 & 1.00 \\
\hline & & $10.00 \%$ & 0.689 & 0.184 & 0.805 & 5.44 \\
\hline & 20 Diं & $14.00 \%$ & 0.765 & 0.133 & 0.831 & 7.51 \\
\hline$\frac{0}{\pi}$ & 3,3-Dimethylgluartic Acid & $17.00 \%$ & 0.804 & 0.109 & 0.845 & 9.19 \\
\hline $\overrightarrow{\mathrm{W}}$ & & $19.5 \%$ & 0.823 & 0.094 & 0.854 & 10.7 \\
\hline$\Xi$ & & $19.75 \%$ & 0.831 & 0.092 & 0.855 & 10.8 \\
\hline 三 & & $0.00 \%$ & 0.000 & 0.000 & 0.502 & 1.00 \\
\hline 8 & & $20.00 \%$ & 0.833 & 0.091 & 0.915 & 11.0 \\
\hline & PEG 12000 & $40.00 \%$ & 0.930 & 0.036 & 0.916 & 27.7 \\
\hline & & $55.0 \%$ & 0.961 & 0.020 & 0.916 & 49.9 \\
\hline & & $55.25 \%$ & 0.961 & 0.020 & 0.916 & 50.4 \\
\hline & & $0.00 \%$ & 0.000 & 0.000 & 0.571 & 1.00 \\
\hline & & $2.00 \%$ & 0.290 & 0.551 & 0.667 & 1.82 \\
\hline & & $5.00 \%$ & 0.513 & 0.332 & 0.743 & 3.11 \\
\hline & & $10.00 \%$ & 0.690 & 0.184 & 0.805 & 5.44 \\
\hline & 3,3-Dimethylgluartic Acid & $28.25 \%$ & 0.887 & 0.060 & 0.875 & 16.8 \\
\hline 웅 & & $30.00 \%$ & 0.896 & 0.055 & 0.878 & 18.1 \\
\hline Eี & & $30.5 \%$ & 0.897 & 0.054 & 0.879 & 18.4 \\
\hline$\Xi$ & & $30.75 \%$ & 0.899 & 0.053 & 0.880 & 18.8 \\
\hline$\Xi$ & & $0.00 \%$ & 0.000 & 0.000 & 0.502 & 1.00 \\
\hline$\Xi$ & & $1.00 \%$ & 0.168 & 0.712 & 0.889 & 1.40 \\
\hline E & & $2.00 \%$ & 0.290 & 0.551 & 0.902 & 1.82 \\
\hline & PEG 12000 & $3.00 \%$ & 0.382 & 0.447 & 0.907 & 2.24 \\
\hline & & $4.25 \%$ & 0.470 & 0.360 & 0.910 & 2.78 \\
\hline & & $4.50 \%$ & 0.485 & 0.347 & 0.910 & 2.88 \\
\hline & & $4.75 \%$ & 0.499 & 0.334 & 0.911 & 2.99 \\
\hline
\end{tabular}



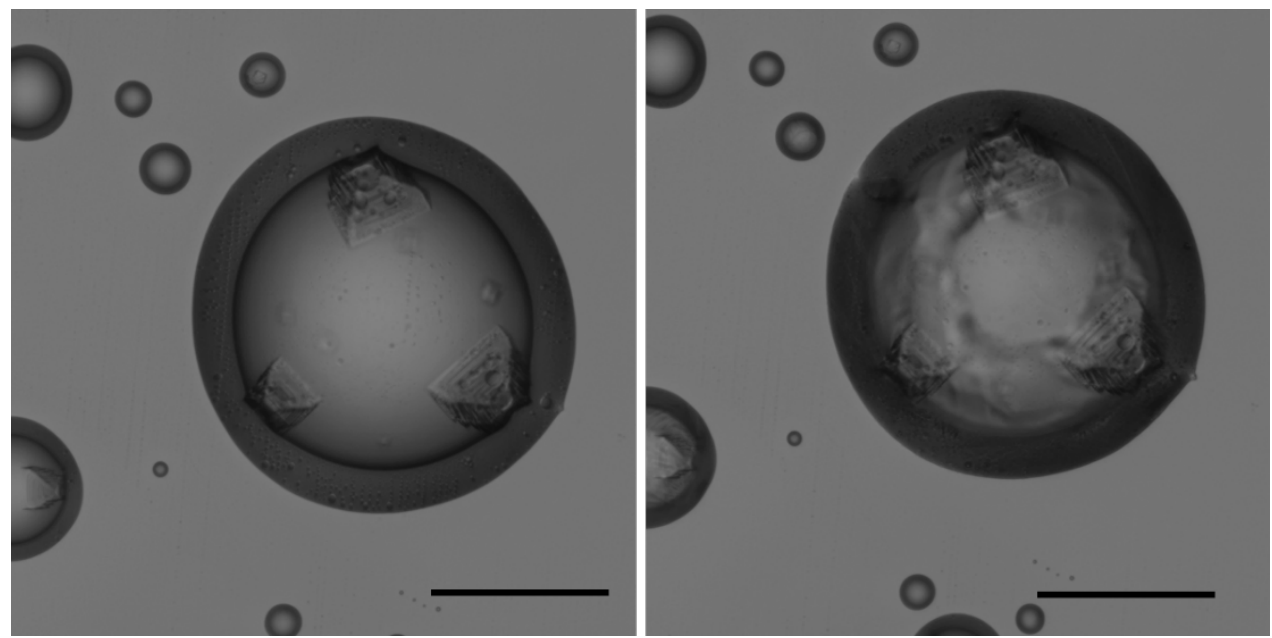

Figure S1: a) The first efflorescence and appearance of sodium chloride crystals in 3,3dimethylglutaric acid/sodium chloride $7 \mathrm{wt} . \%$ sucrose solution b) the complete efflorescence of the same particle

\section{Viscosity and Surface Tension}

Viscosity measurements were taken using an Ares RFS-3 rheometer with cylindrical RSF2 geometry in steady motor mode. The solutions showed Newtonian behavior between 10 and 100 $\mathrm{s}^{-1}$ sheer rate with eleven measurements taken in this range. The value reported is the average of these eleven measurements. Non-sheering solutions have an error of $5 \%$, and the uncertainty reported reflects that error. The concentration of the solutions measured is the estimated concentration of particles equilibrated at $90 \% \mathrm{RH}$. The concentration of the equilibrated particles was estimated by spraying the slides and immediately imaging the particles to obtain their initial volume. The particles were allowed to equilibrate at $90 \%$ until they showed no change in diameter and imaged to determine their volume change from their initial values. Then the particles were lowered to their SRH and allowed to equilibrate at that point after which their volume was determined and its change from the initial value was once again calculated. The initially sprayed particles were assumed to have the concentration of the solution they were sprayed from and using 
$\mathrm{M}_{1} \mathrm{~V}_{1}=\mathrm{M}_{2} \mathrm{~V}_{2}$, where $\mathrm{M}_{1}$ is the $5.0 \mathrm{wt} \%$ organic/inorganic solution with its respective quantity of sucrose, $V_{1}$ is the volume of the particles sprayed from the initial solution, and $\mathrm{M}_{2}$ is the concentration of the particle after equilibration at $90 \%$ or $\mathrm{SRH}$, and $\mathrm{V}_{2}$ is the volume of the particle after equilibration, the estimated concentration of the equilibrated particles was determined. The same procedure was used for both the $90 \% \mathrm{RH}$ concentration estimates and the SRH concentration estimates. This procedure is shown in Figure S2. The density and surface tension of these solutions was measured using a Krüss K11 force tensiometer using a density attachment and a Wilhelmy plate, with three measurements taken for each surface tension and density reported.

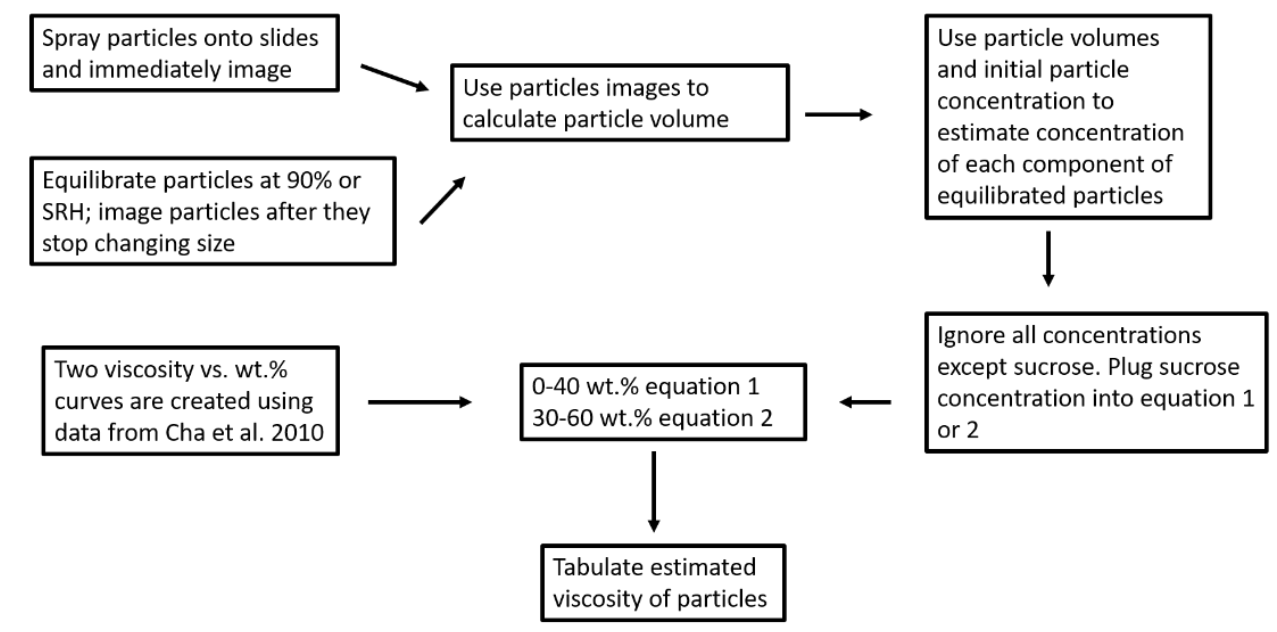

Figure S2: A flow chart summarizing the process used to determine the estimated viscosities of the particles

To better understand the viscosity of these systems, we equilibrated the particles at $90 \% \mathrm{RH}$ and estimated the concentration of the particles based on their diameter. In these calculations, we assumed that the particles exist as perfect half spheres, will shrink equally in all directions other than where the surface is exposed to the substrate, no significant evaporation occurs from spraying, and no density changes occur in the particles. The contact angle is assumed to be $90^{\circ}$ and constant throughout the experiment, which is unlikely to be true. If the contact angle is less than $90^{\circ}$ the concentration estimate will be high whereas if the angle is greater than $90^{\circ}$ the concentration 
estimated will be low. A changing contact angle over the course of the experiment would also shift the concentration estimates either high or low. While contact angles were not measured in this paper, the work of Song et al. was taken into consideration for our error analysis discussion. ${ }^{1} \mathrm{We}$ chose to use the $90 \% \mathrm{RH}$ mark because this is above the DRH for all solutions, allowing us to make these solutions in bulk because the particles are not supersaturated in solute. In addition to viscosity measurements, surface tension and density measurements were taken for these solutions. These data are summarized in Table S3. We see that there are no obvious trends between the surface tension or density with the wt.\% sucrose, the starting SRH values, or the ending SRH values. Similarly, the viscosities of the particles can also be estimated at both $90 \% \mathrm{RH}$ and at the SRH using sucrose solution data from literature. ${ }^{2}$ Research in the atmospheric community has been performed on the viscosities of sucrose particles using a variety of methods such as florescence recovery after photobleaching, droplet coalescence using optical tweezers, and the poke-flow technique. ${ }^{3-6}$ Most of the data obtained in these papers is outside of the range of sucrose concentrations estimated in this paper due to the low concentrations needed to arrest phase separation making it difficult for us to compare our sucrose values with those reported..$^{3-5}$ The sucrose concentrations are estimated using the time-mode $60 \mu \mathrm{W}$ data from Cha et al. ${ }^{2}$ We fit the data using a symmetric sigmoidal curve with the $0-40 \mathrm{wt} . \%$ modeled with one curve and the $40-$ 60 wt.\% modeled with a second curve. Using these curves, we calculated the viscosities of the particles based on their sucrose concentrations and found a linear correlation between the estimated viscosities and the measured viscosities at $90 \% \mathrm{RH}$ (Figure S3). The modeled sucrose concentration curves were also used to estimate the sucrose viscosity at the SRH of each system at the last point before phase separation is arrested (Table S4). The correlation between the measured and estimated sucrose viscosities shown in Figure S3 was not used in the estimates and 
the particles are assumed to contain only sucrose. Using these estimates, we see that the changes in viscosity are within one order of magnitude or less between the estimated viscosity at $90 \% \mathrm{RH}$ and the estimated viscosity at the SRH. The estimated viscosity values are one to three orders of magnitude different from those estimated in Fard et al. because these values are estimated for the homogenous particle as opposed to the different phases of the phase separated particles. ${ }^{7}$ The order of magnitude of our values is supported by modeled viscosities of dicarboxylic acid particles which had estimated viscosities at $0 \%$ RH from $10^{-3}$ to $10^{-1.5} \mathrm{~Pa} \mathrm{~s} .^{8}$ All estimated viscosities at the point where phase separation is arrested are below $0.1 \mathrm{~Pa}$ s showing that viscosity is not likely to be a large factor in the phase separation of these systems. If the salt and organic components were included in the viscosities, we would expect the values to remain within the liquid-like aerosol regime, for most if not all data. We were unable to measure the actual viscosity at the SRH values because we measured the bulk viscosities and the particles are supersaturated at that point making it impossible to make those concentrations of solutions in bulk. We looked for correlations between the starting relative humidity of the systems when they have no sucrose with the last point before phase separation is arrested and included particle viscosity estimates, but did not observe any direct correlations for these data. Additionally, Table S4 provides estimates the concentrations of the sucrose, salt, and organics at the SRH values. From the viscosity data obtained and estimated for the systems studied in this paper, we conclude that it is unlikely that viscosity causes the inhibition of phase separation at the sucrose concentrations studied. 
Table S3: Estimated concentrations at $90 \% \mathrm{RH}$ for the sucrose, salt, and organic components and corresponding viscosity, density, and surface tension measurements of solutions of those concentrations as well as estimated sucrose viscosities.

\begin{tabular}{|c|c|c|c|c|c|c|c|c|}
\hline & & & & $\%$ relative & umidity & & & \\
\hline & & $\begin{array}{l}\text { Wt.\% } \\
\text { Sucrose }\end{array}$ & $\begin{array}{l}\text { Wt.\% } \\
\text { Salt }\end{array}$ & $\begin{array}{l}\text { Wt.\% } \\
\text { Organic }\end{array}$ & $\begin{array}{c}\text { Estimated } \\
\text { Sucrose } \\
\text { Viscosity } \\
(\mathrm{Pa} \mathrm{s})\end{array}$ & $\begin{array}{c}\text { Measured } \\
\text { Viscosity } \\
(\mathrm{Pa} \mathrm{s})\end{array}$ & $\begin{array}{l}\text { Density } \\
\left(\mathrm{g} / \mathrm{cm}^{3}\right)\end{array}$ & $\begin{array}{c}\text { Surface } \\
\text { Tension } \\
(\text { dynes/cm) }\end{array}$ \\
\hline & $\begin{array}{l}\text { 2-Methylglutaric } \\
\text { Acid }\end{array}$ & $\begin{array}{l}8.1 \pm \\
1.4\end{array}$ & $\begin{array}{l}15.4 \pm \\
2.6\end{array}$ & $\begin{array}{l}15.4 \pm \\
2.6\end{array}$ & 0.00105 & $\begin{array}{l}0.0029 \pm \\
0.001\end{array}$ & $\begin{array}{l}1.146 \pm \\
0.004\end{array}$ & $45.7 \pm 0.1$ \\
\hline & $\begin{array}{l}\text { 3-Methylglutaric } \\
\text { Acid }\end{array}$ & $\begin{array}{l}3.6 \pm \\
0.5\end{array}$ & $\begin{array}{l}8.6 \pm \\
1.3\end{array}$ & $\begin{array}{l}8.6 \pm \\
1.3\end{array}$ & 0.00102 & $\begin{array}{l}0.0017 \pm \\
0.0001\end{array}$ & $\begin{array}{l}1.078 \pm \\
0.001\end{array}$ & $53.2 \pm 0.2$ \\
\hline$\frac{\stackrel{\oplus}{\leftrightarrows}}{\leftrightarrows}$ & $\begin{array}{l}3,3- \\
\text { Dimethylglutaric } \\
\text { Acid }\end{array}$ & $\begin{array}{l}33.8 \pm \\
2.2\end{array}$ & $\begin{array}{l}2.9 \pm \\
0.2\end{array}$ & $\begin{array}{l}2.9 \pm \\
0.2\end{array}$ & 0.00507 & $\begin{array}{l}0.0043 \pm \\
0.0002\end{array}$ & $\begin{array}{l}1.158 \pm \\
0.001\end{array}$ & $54.9 \pm 0.1$ \\
\hline 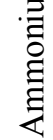 & $\begin{array}{l}2,2- \\
\text { Bis(hydroxymethyl) } \\
\text { butyric Acid }\end{array}$ & 0 & $\begin{array}{l}12.1 \pm \\
4.5\end{array}$ & $\begin{array}{l}8.1 \pm \\
3.0\end{array}$ & -- & $\begin{array}{l}0.0017 \pm \\
0.0001\end{array}$ & $\begin{array}{l}1.091 \pm \\
0.001\end{array}$ & $56.2 \pm 0.4$ \\
\hline & PEG 1000 & $\begin{array}{l}41.8 \pm \\
6.5\end{array}$ & $\begin{array}{l}3.0 \pm \\
0.5\end{array}$ & $\begin{array}{l}3.0 \pm \\
0.5\end{array}$ & 0.00801 & $\begin{array}{l}0.0077 \pm \\
0.0004\end{array}$ & $\begin{array}{l}1.191 \pm \\
0.001\end{array}$ & $62.0 \pm 0.1$ \\
\hline & PEG 12000 & $\begin{array}{l}55.8 \pm \\
6.6\end{array}$ & $\begin{array}{l}4.0 \pm \\
0.5\end{array}$ & $\begin{array}{l}4.0 \pm \\
0.5\end{array}$ & 0.0384 & $\begin{array}{l}0.044 \pm \\
0.002\end{array}$ & $\begin{array}{l}1.267 \pm \\
0.001\end{array}$ & $55.6 \pm 0.1$ \\
\hline & $\begin{array}{l}\text { 2-Methylglutaric } \\
\text { Acid }\end{array}$ & $\begin{array}{l}11.5 \pm \\
1.8\end{array}$ & $\begin{array}{l}4.8 \pm \\
0.7\end{array}$ & $\begin{array}{l}4.8 \pm \\
0.7\end{array}$ & 0.00111 & $\begin{array}{l}0.0017 \pm \\
0.0001\end{array}$ & $\begin{array}{l}1.083 \pm \\
0.001\end{array}$ & $49.0 \pm 0.2$ \\
\hline & $\begin{array}{l}\text { 3-Methylglutaric } \\
\text { Acid }\end{array}$ & $\begin{array}{l}4.3 \pm \\
0.3\end{array}$ & $\begin{array}{l}5.8 \pm \\
0.4\end{array}$ & $\begin{array}{l}5.8 \pm \\
0.4\end{array}$ & 0.00102 & $\begin{array}{l}0.0015 \pm \\
0.0001\end{array}$ & $\begin{array}{l}1.067 \pm \\
0.001\end{array}$ & $56.8 \pm 1.7$ \\
\hline $\begin{array}{l}\frac{\Xi}{0} \\
\Xi \\
\Xi\end{array}$ & $\begin{array}{l}3,3- \\
\text { Dimethylglutaric } \\
\text { Acid }\end{array}$ & $\begin{array}{l}32.2 \pm \\
6.9\end{array}$ & $\begin{array}{l}2.8 \pm \\
0.6\end{array}$ & $\begin{array}{l}2.8 \pm \\
0.6\end{array}$ & 0.00451 & $\begin{array}{l}0.0040 \pm \\
0.0002\end{array}$ & $\begin{array}{l}1.154 \pm \\
0.001\end{array}$ & $54.8 \pm 0.1$ \\
\hline & PEG 1000 & $\begin{array}{l}3.7 \pm \\
0.6\end{array}$ & $\begin{array}{l}5.9 \pm \\
1.0\end{array}$ & $\begin{array}{l}5.9 \pm \\
1.0\end{array}$ & 0.00102 & $\begin{array}{l}0.0017 \pm \\
0.0001\end{array}$ & $\begin{array}{l}1.062 \pm \\
0.001\end{array}$ & $61.5 \pm 0.1$ \\
\hline & PEG 12000 & $\begin{array}{l}12.5 \pm \\
0.3\end{array}$ & $\begin{array}{l}5.4 \pm \\
0.1\end{array}$ & $\begin{array}{l}5.4 \pm \\
0.1\end{array}$ & 0.00115 & $\begin{array}{l}0.0056 \pm \\
0.0003\end{array}$ & $\begin{array}{l}1.089 \pm \\
0.001\end{array}$ & $60.0 \pm 0.1$ \\
\hline
\end{tabular}




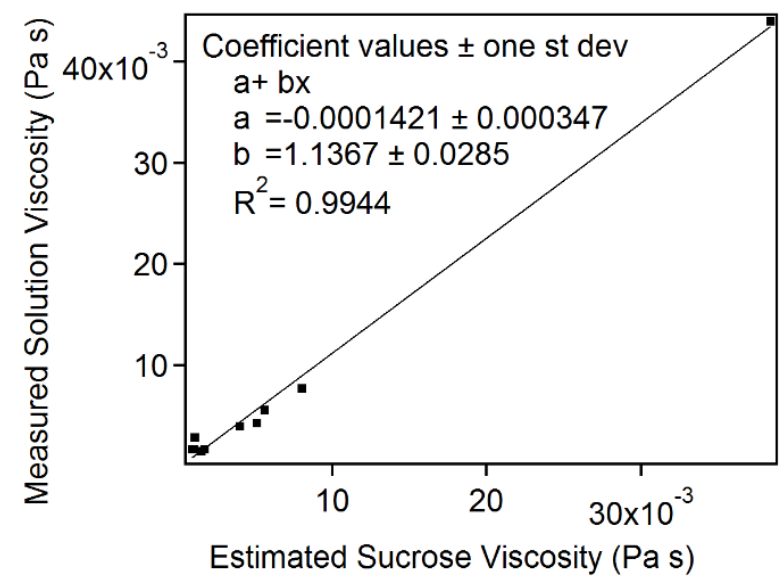

Figure S3: Comparison of the estimated and measured viscosity of the solutions at the 90 $\%$ RH equilibration concentration.

Table S4: Estimated concentrations of sucrose, salt, and organic combinations at their SRH values and estimated sucrose viscosity values of those solutions

\begin{tabular}{|c|c|c|c|c|c|}
\hline & \multicolumn{5}{|c|}{ SRH } \\
\hline & & $\begin{array}{c}\mathrm{Wt} \% \\
\text { Sucrose }\end{array}$ & $\mathrm{Wt} \%$ Salt & $\mathrm{Wt} \%$ Organic & $\begin{array}{c}\text { Estimated } \\
\text { Sucrose } \\
\text { Viscosity } \\
(\mathrm{Pa} \mathrm{s})\end{array}$ \\
\hline \multirow{6}{*}{ 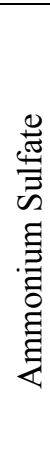 } & 2-Methylglutaric Acid & $10.2 \pm 1.5$ & $19.3 \pm 2.8$ & $19.3 \pm 2.8$ & 0.00108 \\
\hline & 3-Methylglutaric Acid & $5.4 \pm 0.5$ & $13.0 \pm 1.2$ & $13.0 \pm 1.2$ & 0.00103 \\
\hline & 3,3-Dimethylglutaric Acid & $46.8 \pm 2.6$ & $4.0 \pm 0.2$ & $4.0 \pm 0.2$ & 0.0133 \\
\hline & 2,2-Bis(hydroxymethyl) butyric Acid & 0 & $23.7 \pm 7.5$ & $15.8 \pm 5.0$ & 0 \\
\hline & PEG 1000 & $55.4 \pm 9.0$ & $4.0 \pm 0.7$ & $4.0 \pm 0.7$ & 0.0367 \\
\hline & PEG 12000 & $60.7 \pm 6.6$ & $4.2 \pm 0.5$ & $4.2 \pm 0.5$ & 0.0683 \\
\hline \multirow{5}{*}{ 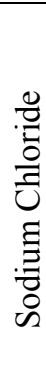 } & 2-Methylglutaric Acid & $20.9 \pm 2.7$ & $8.7 \pm 1.1$ & $8.7 \pm 1.1$ & 0.00182 \\
\hline & 3-Methylglutaric Acid & $8.7 \pm 0.7$ & $11.8 \pm 0.9$ & $11.8 \pm 0.9$ & 0.00105 \\
\hline & 3,3-Dimethylglutaric Acid & $52.5 \pm 10.5$ & $4.5 \pm 0.9$ & $4.5 \pm 0.9$ & 0.0259 \\
\hline & PEG 1000 & $8.2 \pm 1.3$ & $13.0 \pm 2.1$ & $13.0 \pm 2.1$ & 0.00105 \\
\hline & PEG 12000 & $25.8 \pm 0.1$ & $11.2 \pm 0.5$ & $11.2 \pm 0.5$ & 0.00270 \\
\hline
\end{tabular}




\section{References:}

1. Song, M.; Marcolli, C.; Krieger, U. K.; Zuend, A.; Peter, T., Liquid-liquid phase separation and morphology of internally mixed dicarboxylic acids/ammonium sulfate/water particles. Atmos. Chem. Phys. 2012, 12, 2691-2712.

2. Cha, S.; Kim, S. H.; Kim, D., Viscosity of sucrose aqueous solutions measured by fluorescence correlation spectroscopy. J. Korean Phys. Soc. 2010, 56, 1315.

3. Power, R. M.; Simpson, S. H.; Reid, J. P.; Hudson, A. J., The transition from liquid to solid-like behaviour in ultrahigh viscosity aerosol particles. Chem. Sci. 2013, 4, 2597-2604.

4. Chenyakin, Y.; Ullmann, D. A.; Evoy, E.; Renbaum-Wolff, L.; Kamal, S.; Bertram, A. K., Diffusion coefficients of organic molecules in sucrose-water solutions and comparison with StokesEinstein predictions. Atmos. Chem. Phys. 2017, 17, 2423-2435.

5. Kiland, K. J.; Maclean, A. M.; Kamal, S.; Bertram, A. K., Diffusion of Organic Molecules as a Function of Temperature in a Sucrose Matrix (a Proxy for Secondary Organic Aerosol). J Phys Chem Lett 2019, 10, 5902-5908.

6. Grayson, J.; Song, M.; Sellier, M.; Bertram, A., Validation of the poke-flow technique combined with simulations of fluid flow for determining viscosities in samples with small volumes and high viscosities. Atmos Meas Tech 2015, 8, 2463-2472.

7. Fard, M. M.; Krieger, U. K.; Peter, T., Kinetic Limitation to Inorganic Ion Diffusivity and to Coalescence of Inorganic Inclusions in Viscous Liquid-Liquid Phase-Separated Particles. J. Phys. Chem. A 2017, 121, 9284-9296.

8. $\quad$ Song, Y. C.; Haddrell, A. E.; Bzdek, B. R.; Reid, J. P.; Bannan, T.; Topping, D. O.; Percival, C.; Cai, C., Measurements and predictions of binary component aerosol particle viscosity. J Phys Chem $A$ 2016, 120, 8123-8137. 